\title{
YIELD AND QUALITY PERFORMANCES OF VARIOUS ALFALFA (Medicago sativa L.) CULTIVARS IN DIFFERENT SOIL TEXTURES IN A MEDITERRANEAN ENVIRONMENT
}

\author{
Yasar Tuncer KAVUT*, Riza AVCIOGLU \\ Ege University, Faculty of Agriculture, Department of Field Crops, Izmir, TURKEY \\ *Corresponding author: tuncer.kavut@ege.edu.tr
}

Received: 16.03.2015

\begin{abstract}
A field trial was conducted at the experimental fields of Ege University in Bornova and Odemis in 2006 and 2007. The effects of two soil textures (heavy and light) and four cultivars (TT-2008, TT-2009, P-5683 and Elci) on the yield and chemical compositions of some alfalfa cultivars were evaluated under the Mediterranean climatic conditions. The experimental design was a Randomized Complete Blocks with four replications. Results indicated that, the effects of soil texture on yield and quality traits of crop material were significant. TT-2008 and P-5683 alfalfa cultivars had better performances than the other cultivars with regard to yield (fresh herbage, dry matter and crude protein) and quality (contents of dry matter, crude protein, crude ash, ADF and NDF values) characteristics. The overall mean of alfalfa yield at light textured soil condition was significantly higher as compared to the heavy textured soil.
\end{abstract}

Key Words: Alfalfa, Soil texture, Cultivars, Yield, Quality characteristics.

\section{INTRODUCTION}

Alfalfa is one of the most important forage crops worldwide due to its excellent forage quality, high forage yield in a wide range of environments, and high adaptability to different climatic conditions (Moreira and Fageria, 2010). From all forage crops, which together with meadows have a major contribution in ensuring the forage base, alfalfa crop (Medicago sativa L.) occupies an important position. This plant is distinguished by its forage value, vast cultivation area and high digestibility, and from the point of view of farmers and world's agricultural scientist is considered to be the "Queen of Fodder Herbs". From agrobiological point of view, alfalfa gathers also a number of other peculiarities: good revaluation of irrigation water, high capacity for regeneration after mowing, high rate of competitiveness.

According to archaeological information or ancient philosophers, Medicago sativa L. crop has been taken in culture for 4000 years B.C. in regions of southwest Asia (Dale et al., 2012). It has other superior forage qualities and high yields that can be consumed by livestock readily and has high protein content and it is also rich in minerals and vitamins (Soya et al., 2004; Geren et al., 2009). Yield characteristics of alfalfa have been reported as follows; green herbage yield 3520-11660 $\mathrm{kg} \mathrm{ha}^{-1}$, dry matter yield $1780-3230 \mathrm{~kg} \mathrm{ha}^{-1}$ and crude protein yield $246.4-321.3 \mathrm{~kg}$ ha $^{-1}$ (Sengul et al., 2003; Abusuwar and Bakri, 2009;
Saruhan and Kusvuran, 2011; Albayrak and Turk, 2013; Mala and Fadlalla, 2013).

In several studies, quality properties of alfalfa have been reported as $23.4-24.0 \%, 18.9-22.7 \%, 7.5-9.7 \%, 27.5-$ $42.9 \%$ and $39.3-50.3 \%$ for dry matter content, crude protein, crude ash, acid detergent fiber (ADF) and neutral detergent fiber (NDF) respectively (Tomic et al., 2006; Geren et al., 2009; Tongel and Ayan, 2010; Saruhan and Kusvuran, 2011; Albayrak and Turk, 2013). Alfalfa leaves serve as a factory for raw, biodegradable plastic beads, other industrial products or better livestock feed, while the stem goes to ethanol production. Alfalfa has an area of 628.641 ha and 12.6 million ton fresh herbage production quantity in Turkey (Anonymous, 2013). Despite all these advantages, the alfalfa planting area in Turkey is limited and far from to meet the need for quality roughage (Avcioglu et al., 2001). Therefore, to increase alfalfa planting areas in the country, it is important to find the alfalfa varieties suitable to different ecological regions mainly with proper soil textures (Cinar and Hatipoglu, 2014)

Soil texture, which affects the soil's ability to hold onto nutrients and water (Anonymous, 2005). Coarsetextured soils generally have high infiltration rates with good penetration by roots. Many studies on coarse textured soil displayed the dry matter yield of alfalfa superiority of to fine textured soils (Rechel et al., 1991; 
Geren et al., 2009). In the coastal regions, non-dormant alfalfa cultivars suitable to warm, humid climates are common (Sheaffer et al., 1998). However, in the cool and high plateaus of eastern Turkey dormant and cold tolerant cultivars can be grown successfully (Altinok and Karakaya, 2002). There are many ongoing researches on alfalfa at different ecologies of the world and multi location trials including diversity of soil textures are important for releasing new developed varieties (Meyer, 2005; Avci et al., 2013).

The objective of this study was to determine the suitable alfalfa cultivar for the Ege region, a Mediterranean environment with high forage yield and quality by testing at two locations with different soil texture for 2 years.

\section{MATERIALS AND METHODS}

\section{Location of the Experiment}

The trial was carried out during the 2006 and 2007 growing seasons at Bornova experimental fields $\left(38^{\circ} 27.236 \mathrm{~N}, 27^{\circ} 13.576 \mathrm{E}, 28 \mathrm{~m}\right.$ a.s.l) of the Faculty of Agriculture Department of Field Crops and at Odemis experimental fields $\left(38^{\circ} 13.234 \mathrm{~N}, 27^{\circ} 57.880 \mathrm{E}, 115 \mathrm{~m}\right.$ a.s.l) of Odemis Vocational Training College of the Ege University. Meteorological data and the soil properties of locations are presented in Table 1 and 2, respectively. As can be seen in Table 2, heavy soil texture is represented by Bornova whereas light soil by the Odemis location.

Table 1. Some physical and chemical characteristics of the soils of the experimental sites

\begin{tabular}{llllll}
\hline Characteristics & Bornova & Odemis & Characteristics & Bornova & Odemis \\
\hline Sand $(\%)$ & 24.72 & 68.72 & Organic Matter $(\%)$ & 1.13 & 1.58 \\
Silt $(\%)$ & 42.72 & 24.00 & $\mathrm{CaCO}_{3}(\%)$ & 21.52 & 1.44 \\
Clay $(\%)$ & 32.56 & 7.28 & $\mathrm{~N}(\%)$ & 0.11 & 0.16 \\
$\mathrm{pH}$ & 7.80 & 7.28 & $\mathrm{P}(\mathrm{ppm})$ & 40.52 & 20.50 \\
\hline
\end{tabular}

Table 2. Some meteorological data for the experimental sites

\begin{tabular}{|c|c|c|c|c|c|c|}
\hline \multicolumn{7}{|c|}{ Temperature $\left({ }^{\circ} \mathrm{C}\right)$} \\
\hline \multicolumn{2}{|r|}{2006} & \multicolumn{3}{|c|}{2007} & \multicolumn{2}{|c|}{ Long year average } \\
\hline Monhts & Bornova & Odemis & Bornova & Odemis & Bornova & Odemis \\
\hline April & 16.8 & 16.2 & 16.2 & 14.7 & 15.1 & 14.6 \\
\hline May & 21.0 & 20.5 & 22.4 & 21.7 & 20.3 & 19.9 \\
\hline June & 26.2 & 25.4 & 27.5 & 27.1 & 25.5 & 25.0 \\
\hline July & 28.5 & 27.9 & 30.1 & 29.5 & 28.0 & 27.5 \\
\hline Aug & 29.2 & 28.4 & 29.2 & 28.8 & 27.3 & 26.6 \\
\hline Sept. & 23.5 & 22.8 & 24.4 & 23.0 & 22.9 & 22.1 \\
\hline Oct. & 18.3 & 17.9 & 19.7 & 18.3 & 18.0 & 16.9 \\
\hline Nov. & 11.4 & 10.2 & 12.0 & 17.9 & 12.8 & 11.4 \\
\hline Mean & 21.9 & 21.2 & 22.7 & 22.6 & 21.2 & 20.5 \\
\hline \multicolumn{7}{|c|}{ Precipitation (mm) } \\
\hline & 2006 & & 2007 & & Long yea & age \\
\hline Aylar & Bornova & Odemis & Bornova & Odemis & Bornova & Odemis \\
\hline April & 27.0 & 14.1 & 19.3 & 35.4 & 49.5 & 54.8 \\
\hline May & 0.0 & 21.4 & 44.1 & 31.5 & 30.6 & 26.6 \\
\hline June & 19.2 & 6.2 & 0.3 & 6.8 & 9.0 & 10.4 \\
\hline July & 0.0 & 22.0 & 0.0 & 0.0 & 3.2 & 5.1 \\
\hline Aug & 0.0 & 0.0 & 0.0 & 0.0 & 1.6 & 1.6 \\
\hline Sept. & 133.5 & 66.9 & 0.0 & 7.0 & 16.1 & 14.8 \\
\hline Oct. & 88.6 & 77.0 & 107.7 & 74.5 & 37.3 & 34.1 \\
\hline Nov. & 46.7 & 65.1 & 138.5 & 138.5 & 95.8 & 85.5 \\
\hline Total & 315.0 & 272.7 & 309.9 & 293.7 & 243.1 & 232.9 \\
\hline
\end{tabular}

\section{Field applications and the experimental design}

The experiment was carried out in a Randomized Complete Block Design with four replications. Four alfalfa cultivars (TT-2008, TT-2009, P-5683 and Elci) were used as plant material. Seeding rate was $20 \mathrm{~kg} \mathrm{ha}^{-1}$ for all cultivars (Soya et al., 2004). Each plot size was $2 \mathrm{~m}$ x $5 \mathrm{~m}=10 \mathrm{~m}^{2}$. Sowing was made by hand, on September $17^{\text {th }}, 2005$ at Bornova and September $19^{\text {th }}, 2005$ at Odemis.

The soil was harrowed 10 days before planting, then $30 \mathrm{~kg} \mathrm{ha}^{-1} \mathrm{~N}$ and $100 \mathrm{~kg} \mathrm{ha}^{-1} \mathrm{P}_{2} \mathrm{O}_{5}$ were broadcasted and disked to produce a smooth seed bed. Since there were no significant problems of pests, diseases or weeds in the study, no chemical was applied. None of the alfalfa seeds 
were inoculated with Rhizobium bacteria, which existed naturally in the soil. All plants were irrigated throughout the growing season according to morphological appearance of plants in both years.

\section{Measurements and chemical analysis}

The plots were cut at the 10-25\% flowering stage, cutting mid 6 rows of plots in order to avoid border effects (net $4.8 \mathrm{~m}^{2}$ ), by cutting the plants leaving a $5 \mathrm{~cm}$ stubble height (Avcioglu et al., 2001). After 6 cuts in the first and 8 cuts in the second experimental year, harvested fresh forage were weighed and dried to a constant weight at $70^{\circ} \mathrm{C}$ during $48 \mathrm{~h}$. Crude ash was determined at $550{ }^{\circ} \mathrm{C}$ (Bulgurlu and Ergul, 1978). The dried samples were ground in a mill passed through a $1 \mathrm{~mm}$ screen. The crude protein content (CPC) was calculated by multiplying the Kjeldahl N concentration by 6.25 (Kacar and Inal, 2008). The neutral detergent fibre (NDF) and acid detergent fibre (ADF) concentrations were measured according to Ankom
Technology (Ankom 2000 Fiber Analyzer, Ankom Technology Corp., Fairport, NY, USA).

\section{Statistical analysis}

Statistical analyses were done by using the TOTEMSTAT Statistical program (Acikgoz et al., 2004). The treatment means were compared by the LSD test described by Steel and Torrie (1980).

\section{RESULTS AND DISCUSSION}

The results of the analysis of variance of the data combined over 2 years and 2 locations (soil texture) are shown in Table 3. It can be seen in Table 3 that year, cultivar, soil texture had significant $\mathrm{F}$ values for the fresh herbage yield (FHY), dry matter yield (DMY), crude protein yield (CPY) and dry matter content (DMC). Year $x$ cultivar interaction was significant for the FHY, DMY and CPY. The $\mathrm{F}$ value of cultivar $\mathrm{x}$ soil texture interaction was significant for the DMY and the DMC.

Table 3. Results of analysis of variance and the $\mathrm{F}$ values of the traits measured

\begin{tabular}{llllll}
\hline Source of Variation & DF & FHY & DMY & CPY & DMC \\
\hline Year (Y) & 1 & $340.745 * *$ & $368.200 * *$ & $284.255^{* *}$ & $89.194 * *$ \\
Cultivar (C) & 3 & $77.21 *^{* *}$ & $87.789 * *$ & $61.388^{* *}$ & $26.905 * *$ \\
Soil Texture (ST) & 1 & $10.993 * *$ & $27.705 * *$ & $20.049 * *$ & $32.887 * *$ \\
YxC & 3 & $18.001 * *$ & $13.611 * *$ & $10.374 * *$ & $2.218 \mathrm{~ns}$ \\
YxST & 1 & $1.004 \mathrm{~ns}$ & $3.146 \mathrm{~ns}$ & $3.780 \mathrm{~ns}$ & $1.871 \mathrm{~ns}$ \\
CxST & 3 & $1.928 \mathrm{~ns}$ & $3.209 *$ & $2.098 \mathrm{~ns}$ & $7.694 * *$ \\
YxCxST & 3 & $0.277 \mathrm{~ns}$ & $0.042 \mathrm{~ns}$ & $0.190 \mathrm{~ns}$ & $0.617 \mathrm{~ns}$ \\
CV $(\%)$ & & 4.99 & 5.98 & 7.08 & 2.35 \\
\hline Source of Variation & DF & CPC & CAC & ADF & NDF \\
\hline Year (Y) & 1 & $1.762 \mathrm{~ns}$ & $0.012 \mathrm{~ns}$ & $0.003 \mathrm{~ns}$ & $23.708 * *$ \\
Cultivar (C) & 3 & $0.578 \mathrm{~ns}$ & $1.053 \mathrm{~ns}$ & $16.399 * *$ & $14.504 * *$ \\
Soil Texture (ST) & 1 & $0.001 \mathrm{~ns}$ & $1.010 \mathrm{~ns}$ & $0.000 \mathrm{~ns}$ & $0.970 \mathrm{~ns}$ \\
YxC & 3 & $1.163 \mathrm{~ns}$ & $0.195 \mathrm{~ns}$ & $0.673 \mathrm{~ns}$ & $2.210 \mathrm{~ns}$ \\
YxST & 1 & $0.696 \mathrm{~ns}$ & $0.100 \mathrm{~ns}$ & $2.580 \mathrm{~ns}$ & $4.073 *$ \\
CxST & 3 & $0.050 \mathrm{~ns}$ & $1.152 \mathrm{~ns}$ & $0.537 \mathrm{~ns}$ & $1.197 \mathrm{~ns}$ \\
YxCxST & 3 & $0.392 \mathrm{~ns}$ & $0.139 \mathrm{~ns}$ & $0.505 \mathrm{~ns}$ & $1.485 \mathrm{~ns}$ \\
CV $(\%)$ & & 3.22 & 10.85 & 4.10 & 3.48 \\
\hline
\end{tabular}

Abbreviations: DF: Degrees of freedom; CV: Coefficient of variation, NS: Not significant, *: P<0.05, **: P<0.01, FHY: Fresh herbage yield, DMY: Dry matter yield, CPY: Crude protein yield, DMC: Dry matter yield, CPC: Crude protein content, CAC: Crude ash content, ADF: Acid detergent fiber, NDF: Neutral detergent fiber

The significant variation of year, soil texture, cultivar and year $\mathrm{x}$ cultivar interaction indicated the treatment of results separately at heavy textured and light textured soil and to compare the means by using the LSD based on significant $F$ values shown in Table 3.

\section{Yield parameters}

The means of the alfalfa cultivars for FHY, DMY and CPY are shown in Table 4. Average fresh herbage yield of P-5683 (139688 $\left.\mathrm{kg} \mathrm{ha}^{-1}\right)$ was highest in 2007 while yields of Elci $\left(86781 \mathrm{~kg} \mathrm{ha}^{-1}\right)$ and TT-2009 (89688 kg ha-1) were lower in 2006. In two years average, both cultivars of P5683 (118844 kg ha $\left.{ }^{-1}\right)$ and TT-2008 (117594 kg ha-1) had the highest fresh herbage yield. These could be due to the different genotypic characteristics of the cultivars tested in the experiment and it appears that adaptable cultivars for specific conditions should be recommended for proper regions (Altinok and Karakaya, 2002; Abusuwar and Bakri, 2009; Saruhan and Kusvuran, 2011; Cinar and Hatipoglu, 2014). Average fresh herbage yield of alfalfa cultivars grown on light soil $\left(110408 \mathrm{~kg} \mathrm{ha}^{-1}\right)$ were also higher compared to heavy soil $\left(105930 \mathrm{~kg} \mathrm{ha}^{-1}\right)$ in two years average, evidencing the superiority of light soil conditions over the heavy soil. These results were in agreement with Forbes and Watson (1992) who stated that soil factors, which influence root growth and development and thereby affect the yield of a crop, can be classified as nutritional, biological or physical including soil temperature, aeration and resistance to penetration by roots. As it is expected the fresh herbage yields of all tested alfalfa cultivars, being perennial crops, increased significantly in the second year compared to the first year. 
Table 4. Yield performances of four alfalfa cultivars in two different soil textures

\begin{tabular}{|c|c|c|c|c|c|c|c|c|c|}
\hline \multirow{3}{*}{ Cultivars } & \multicolumn{3}{|c|}{2006} & \multicolumn{3}{|c|}{2007} & \multicolumn{3}{|c|}{ 2006-2007 } \\
\hline & \multicolumn{3}{|c|}{ Soil Texture (ST) } & \multicolumn{3}{|c|}{ Soil Texture (ST) } & \multicolumn{3}{|c|}{ Soil Texture (ST) } \\
\hline & Light & Heavy & Mean & Light & Heavy & Mean & Light & Heavy & Mean \\
\hline \multicolumn{10}{|c|}{ Fresh Herbage Yield (kg ha- $\left.{ }^{1}\right)$} \\
\hline TT-2008 & 113000 & 103688 & $108344 \mathrm{~b}$ & 131688 & 122000 & $126844 \mathrm{a}$ & 122344 & 112844 & 117594 \\
\hline TT-2009 & 90625 & 88750 & 89688 b & 113825 & 111188 & $112506 \mathrm{a}$ & 102225 & 99969 & 101097 \\
\hline P-5683 & 97750 & 98250 & $98000 \mathrm{~b}$ & 141000 & 138375 & $139688 \mathrm{a}$ & 119375 & 118313 & 118844 \\
\hline Elci & 87688 & 85875 & $86781 \mathrm{~b}$ & 107688 & 99313 & $103500 \mathrm{a}$ & 97688 & 92594 & 95141 \\
\hline Mean & 97266 & 94140 & 95703 & 123550 & 117719 & 120634 & 110408 & 105930 & 108169 \\
\hline \multicolumn{10}{|c|}{ Dry Matter Yield $\left(\right.$ kg ha- $\left.^{1}\right)$} \\
\hline TT-2008 & 25130 & 22150 & $23640 \mathrm{~b}$ & 32193 & 27753 & $29973 \mathrm{a}$ & $28661 \mathrm{a}$ & $24951 \mathrm{a}$ & 26806 \\
\hline TT-2009 & 19405 & 18895 & $19150 \mathrm{~b}$ & 25913 & 24558 & $25235 \mathrm{a}$ & $22659 \mathrm{~b}$ & $21726 \mathrm{~b}$ & 22193 \\
\hline P-5683 & 22345 & 21090 & $21718 b$ & 33710 & 31130 & $32420 \mathrm{a}$ & $28028 \mathrm{a}$ & $26110 \mathrm{a}$ & 27069 \\
\hline Elci & 18198 & 17918 & $18058 \mathrm{~b}$ & 23445 & 21688 & $22566 \mathrm{a}$ & $20821 \mathrm{c}$ & $19803 \mathrm{c}$ & 20312 \\
\hline Mean & 21269 & 20013 & 20641 & 28815 & 26282 & 27548 & 25042 & 23148 & 24095 \\
\hline \multicolumn{10}{|c|}{ Crude Protein Yield (kg ha- ${ }^{1}$ ) } \\
\hline TT-2008 & 4940 & 4428 & $4684 \mathrm{~b}$ & 6588 & 5650 & $6119 \mathrm{a}$ & 5764 & 5039 & 5401 \\
\hline TT-2009 & 3865 & 3745 & $3805 \mathrm{~b}$ & 5208 & 4968 & $5088 \mathrm{a}$ & 4536 & 4356 & 4446 \\
\hline P-5683 & 4400 & 4170 & $4285 \mathrm{~b}$ & 6748 & 6180 & $6464 \mathrm{a}$ & 5574 & 5175 & 5374 \\
\hline Elci & 3645 & 3643 & $3644 \mathrm{~b}$ & 4728 & 4280 & $4504 \mathrm{a}$ & 4186 & 3961 & 4074 \\
\hline Mean & 4213 & 3996 & 4104 & 5818 & 5269 & 5543 & 5015 & 4633 & 4824 \\
\hline
\end{tabular}

There were significant differences with regard to the dry matter yields among the cultivars and average dry matter yields of TT-2008 and P-5683 (28661 kg ha-1 and $28028 \mathrm{~kg} \mathrm{ha}^{-1}$, respectively) were higher than other tested crop material in light soil whereas Elci had the lowest dry matter yield (19803 $\mathrm{kg} \mathrm{ha}^{-1}$ ) in heavy soil in two years average. Some researchers also pointed out that dry matter yield characteristic is closely related to the overall growth performances of alfalfa crops (such as fresh herbage yield and dry matter content) and there is great variation among various cultivars (Andueza et al., 2001; Abusuwar and Bakri, 2009; Basbag et al., 2009). Average dry matter yield of alfalfa cultivars grown on light soil $(25042 \mathrm{~kg}$ ha $\left.{ }^{1}\right)$ were significantly higher compared to heavy soil (23148 $\mathrm{kg} \mathrm{ha}^{-1}$ ), displaying the favourable textures of light soils for alfalfa root development and growth. Some researchers, confirming our present results, also compared the yield of alfalfa on light and heavy soil under Mediterranean conditions over 3 years and emphasized that alfalfa produced significantly higher dry matter yield in light soil (Avcioglu et al., 2001; Geren et al., 2009).

Average crude protein yield of P-5683 (6464 $\left.\mathrm{kg} \mathrm{ha}^{-1}\right)$ was highest in 2007 whereas Elci and TT-2009 (3644 kg $\mathrm{ha}^{-1}$ and $3805 \mathrm{~kg} \mathrm{ha}^{-1}$, respectively) performed worse than the others in 2006. These crude protein yield performances were the natural results of the fresh herbage yield variations displayed by different alfalfa cultivars tested and soil types. The statements of Sengul et al. (2003); Geren et al. (2009); Avci et al. (2013) confirmed our results. Average crude protein yield of alfalfa cultivars grown on light soil (5015 $\mathrm{kg} \mathrm{ha}^{-1}$ ) were higher than heavy soil (4633 $\mathrm{kg} \mathrm{ha}^{-1}$ ), displaying again the favourable textures of light soils for alfalfa development. In two years average, TT-2008 (5401 kg ha-1) and P-5683 (5374 kg ha $\left.{ }^{1}\right)$ cultivars displaying higher crude protein yield (Table 4), namely a better feed quality which is accepted as a vital peculiarity in alfalfa hay (Al-Suhaibani, 2010; Mala and Fadlalla, 2013) had also higher crude protein yields than other crop material tested, while all cultivars showed a better performance in the light textured soil.

\section{Quality parameters}

The results of statistical analysis indicated that only the effects of experimental factors and CxST interaction effect were significant for the dry matter content of alfalfa cultivars, whereas there were not any significant factor or interaction effect on the crude protein and the crude ash content characteristics (Table 5).

Dry matter content results also showed that P-5683 and TT-2008 (23.38\% and $23.34 \%$, respectively) had higher values than other cultivars in light soils. Average dry matter contents of cultivars were higher in light than heavy soil and also significantly higher in the second experimental year. As stated by many research workers, dry matter content of forage crops is one of the dependable criteria of biomass production and high rate of dry matter content is mostly indicate a better adaptability and yield performance. Our findings confirmed these approaches and other researcher's statements (Avcioglu et al., 2001; Abusuwar and Bakri, 2009; Basbag et al., 2009).

The trends of crude protein and crude ash contents of alfalfa cultivars were similar to each other. Although those nutritional trait variations were not significant, the crude protein and crude ash contents of the cultivars ranged between limited values in both years and 2 years average (19.81-20.16 and 8.40-9.52\%, respectively). The reason for having no striking variation in terms of either crude protein or crude ash content could be that all tested alfalfa crops were cut in similar flowering stages (10-25\% flowering) during harvest procedures. Present results indicated that the crude protein and crude ash contents of 
tested crop materials represented the high quality legume hay and the values were in agreement with those of many researchers (Sheaffer et al., 1998; Avcioglu et al., 2001; Avci et al., 2013).

Table 5. Quality performances of four alfalfa cultivars in two different soil textures

\begin{tabular}{|c|c|c|c|c|c|c|c|c|c|}
\hline \multirow{3}{*}{ Cultivars } & \multicolumn{3}{|c|}{2006} & \multicolumn{3}{|c|}{2007} & \multicolumn{3}{|c|}{ 2006-2007 } \\
\hline & \multicolumn{3}{|c|}{ Soil Texture (ST) } & \multicolumn{3}{|c|}{ Soil Texture (ST) } & \multicolumn{3}{|c|}{ Soil Texture (ST) } \\
\hline & Light & Heavy & Mean & Light & Heavy & Mean & Light & Heavy & Mean \\
\hline \multicolumn{10}{|c|}{ Dry Matter Content (\%) } \\
\hline TT-2008 & 22.22 & 21.36 & 21.79 & 24.45 & 22.75 & 23.60 & $23.34 \mathrm{a}$ & $22.06 \mathrm{a}$ & 22.70 \\
\hline TT-2009 & 21.41 & 21.29 & 21.35 & 22.76 & 22.09 & 22.42 & $22.09 \mathrm{~b}$ & $21.69 \mathrm{ab}$ & 21.89 \\
\hline P-5683 & 22.85 & 21.45 & 22.15 & 23.91 & 22.50 & 23.20 & $23.38 \mathrm{a}$ & $21.97 \mathrm{a}$ & 22.68 \\
\hline Elci & 20.75 & 20.87 & 20.81 & 21.74 & 21.84 & 21.79 & $21.25 \mathrm{c}$ & $21.35 \mathrm{~b}$ & 21.30 \\
\hline Mean & 21.81 & 21.24 & 21.52 & 23.22 & 22.29 & 22.75 & 22.51 & 21.77 & 22.14 \\
\hline \multicolumn{10}{|c|}{ Crude Protein Content (\%) } \\
\hline TT-2008 & 19.68 & 19.94 & 19.81 & 20.47 & 20.37 & 20.42 & 20.07 & 20.16 & 20.11 \\
\hline TT-2009 & 19.93 & 19.82 & 19.87 & 20.08 & 20.23 & 20.16 & 20.00 & 20.03 & 20.01 \\
\hline P-5683 & 19.70 & 19.77 & 19.73 & 20.01 & 19.84 & 19.93 & 19.85 & 19.81 & 19.83 \\
\hline Elci & 20.04 & 20.32 & 20.18 & 20.16 & 19.72 & 19.94 & 20.10 & 20.02 & 20.06 \\
\hline Mean & 19.83 & 19.96 & 19.90 & 20.18 & 20.04 & 20.11 & 20.01 & 20.00 & 20.01 \\
\hline \multicolumn{10}{|c|}{ Crude Ash Content (\%) } \\
\hline TT-2008 & 9.36 & 8.79 & 9.07 & 9.03 & 9.14 & 9.08 & 9.19 & 8.96 & 9.08 \\
\hline TT-2009 & 9.40 & 9.16 & 9.28 & 9.63 & 9.53 & 9.58 & 9.52 & 9.35 & 9.43 \\
\hline P-5683 & 8.72 & 9.33 & 9.03 & 8.80 & 9.30 & 9.05 & 8.76 & 9.31 & 9.04 \\
\hline Elci & 8.49 & 9.37 & 8.93 & 8.31 & 9.10 & 8.71 & 8.40 & 9.24 & 8.82 \\
\hline Mean & 8.99 & 9.16 & 9.08 & 8.94 & 9.27 & 9.11 & 8.97 & 9.22 & 9.10 \\
\hline \multicolumn{10}{|c|}{ ADF (\%) } \\
\hline TT-2008 & 35.58 & 34.24 & 34.91 & 35.09 & 36.52 & 35.80 & 35.33 & 35.38 & $35.36 \mathrm{~b}$ \\
\hline TT-2009 & 38.20 & 37.95 & 38.07 & 37.51 & 38.29 & 37.90 & 37.85 & 38.12 & $37.99 \mathrm{a}$ \\
\hline P-5683 & 36.93 & 35.76 & 36.34 & 36.24 & 35.81 & 36.02 & 36.59 & 35.78 & $36.18 \mathrm{~b}$ \\
\hline Elci & 38.76 & 39.05 & 38.91 & 38.11 & 38.73 & 38.42 & 38.43 & 38.89 & $38.67 \mathrm{a}$ \\
\hline Mean & 37.37 & 36.75 & 37.06 & 36.74 & 37.34 & 37.04 & 37.05 & 37.04 & 37.05 \\
\hline \multicolumn{10}{|c|}{ NDF (\%) } \\
\hline TT-2008 & 45.14 & 45.18 & 45.16 & 47.20 & 46.16 & 46.68 & 46.17 & 45.67 & 45.92 \\
\hline TT-2009 & 45.49 & 48.24 & 46.86 & 51.07 & 49.78 & 50.42 & 48.28 & 49.01 & 48.64 \\
\hline P-5683 & 44.82 & 44.47 & 44.64 & 48.18 & 45.59 & 46.88 & 46.50 & 45.03 & 45.76 \\
\hline Elci & 48.48 & 47.73 & 48.11 & 48.79 & 48.78 & 48.79 & 48.64 & 48.26 & 48.45 \\
\hline Mean & $45.98 \mathrm{~b}$ & $46.40 \mathrm{~b}$ & 46.19 & $48.81 \mathrm{a}$ & $47.58 \mathrm{a}$ & 48.19 & 47.39 & 46.99 & 47.19 \\
\hline
\end{tabular}

The effects of YxST interaction and $\mathrm{Y}$ and $\mathrm{C}$ on NDF value were significant, while the other two or three way interactions were not (Table 5). The average NDF value of light soil in 2007 was the highest $(48.81 \%)$, whereas average NDF values of both soil types were lower than others in 2006 which was the indication of higher quality (Table 5). In terms of NDF variation among the cultivars, TT-2009 and Elci (48.64\% and 48.45\%, respectively) had higher values, while P-5683 and TT-2008 (45.76\% and $45.92 \%$, respectively) had lower NDF values. Only the effects of different cultivars were statistically significant on ADF content (Table 5). ADF contents of alfalfa cultivars ranged between 35.36-38.67 \% and higher ADF values were recorded in Elci and TT-2009 (38.67\% and $37.99 \%$, respectively), whereas TT-2008 and P-5683 had lower $\mathrm{ADF}$ rates $(35.36 \%$ and $36.18 \%$ respectively) indicating higher feed quality. The NDF and ADF values of alfalfa cultivars tested in the experiment were consistent with the findings of various researchers (Markovic et al., 2007; Dale et al., 2012).
In general, stem cell wall constituents (NDF, ADF, ADL, cellulose, and hemicellulose) are highly positively correlated with each other, but negatively associated with crude protein (Jarrige et al., 1988; Erkovan et al., 2009). NDF is the amount of protective substances obtained from residue after boiling a fodder sample in neutral detergent solution. NDF residue, actually contains very little pectic substances, but may contain negligible amounts of products like starch, nitrogenous substances and tannins (Kiraz, 2011; Selmi et al., 2013). The amount of protective substances residue obtained after boiling the sample feed with detergent solution is called ADF. ADF content is regularly higher than the crude fiber from forage, these features being closely related, since both are an estimate of the amount of cellulose + lignin (Jarrige et al., 1988). Overall results of ADF and NDF contents indicated that TT-2008 and P-5683 cultivars, having lower $\mathrm{ADF}$ and NDF values throughout the experimental years, had the higher feed quality. Those cultivars also ranked first according to the Feed Quality Ranking List of American Forage and Grassland Council (Rohweder et al., 
1978). Many researchers working on alfalfa forage quality indicated that protein and ash content are favourable properties to increase the nutritional value of material whereas cellulose and related derivatives are unfavourable contents (Riday and Brummer, 2005; Dale et al., 2012). Considering this approach, it can be concluded that tested cultivars were significantly different in term of cellulose, hemicellulose and lignin content depending on their genetic properties. Riday and Brummer (2005) also stated that alfalfa nutritive value traits rarely exhibit genotype by environment interaction. These nutritional characteristics can be considered as a selection criteria to choose proper cultivars for this type of ecologies and soil types.

\section{CONCLUSION}

In conclusion, it could be suggested that alfalfa cultivation on light soil had many advantages including higher biomass production and forage quality as compared to practices on heavy soil under the Mediterranean climatic conditions. TT-2008 and P-5683 cultivars of alfalfa are the most adaptable and promising forage crop material for this type of Mediterranean ecologies. Moreover, these cultivars should be considered as parents the for future breeding programmes in the area.

\section{LITERATURE CITED}

Abusuwar, A.O. and E. Bakri. 2009. Effect of water quality and weeding on yield and quality of three alfalfa (Medicago sativa 1.) cultivars. Austrialian Journal of Crop Science, 3(6), p: $315-321$.

Acikgoz, N., E. Ilker and A. Gokcol. 2004. Assessment of biological research on the computer. EU TOTEM, İzmir (in Turk1sh).

Al-Suhaibani, N.A. 2010. Estimation yield and quality of alfalfa and clover for mixture cropping pattern at different seeding rates. American-Eurasian Journal Agriculture \& Environment Sci., 8 (2), p: 189-196.

Albayrak, S. and M. Turk. 2013. Changes in the forage yield and quality of legume-grass mixtures throughout a vegetation period. Turkish Journal of Agriculture and Forestry, 37, p: 139-147.

Altinok, S. and A. Karakaya. 2002. Forage yield of different alfalfa cultivars under Ankara conditions. Turkish Journal of Agriculture and Forestry, 26, p: 11-16.

Andueza, D., F. Munoz, A. Maisterra and I. Delgado. 2001. Forage yield and crude protein content of lucerne cultivars established in the ebro middle valley. Preliminar results. In: Options Méditerranéennes. Series A: Séminaires Méditerranéens, 45, p: 73-76.

Anonymous. 2013. Turkish statistical institute. http://www.turkstat.gov.tr (Accessed November 24, 2014).

Anonymous. 2005. Fertilising dairy pastures: A manual for use in the Target 10 Soils and Fertilisers Program. Department of Primary Industries, Melbourne, Victoria, Australia, ISBN 1741462193, 2nd ed., 318p.

Avci, M.A., A. Ozkose and A. Tamkoc. 2013. Determination of yield and quality characteristics of alfalfa (Medicago sativa 1.) varieties grown in different locations. Journal of Animal and Veterinary Advances, 12 (4), p: 487-490.

Avcioglu, R., H. Geren and H. Ozkul. 2001. Seasonal changes of quantitative and qualitative performances of some alfalfa cultivars in the Mediterranean coastal part of Aegean Region. Options méditerranéennes, Numero a-45: Quality in lucerne and medics for animal production, 14-16 September 2001, Zaragoza (Spain), CHIEAM, FAO, p: 205-209.

Basbag, M., R. Demirel and M. Avci. 2009. Determination of some agronomical and quality properties of wild alfalfa (Medicago sativa 1.) clones in turkey. Journal of Food, Agriculture \& Environment Vol. 7 (2), p: 357-359.

Cinar, S. and R. Hatipoglu. 2014. Forage yield and botanical composition of mixtures of some perennial warm season grasses with alfalfa (Medicago sativa L.) under Mediterranean conditions. Turk J Field Crops, 19(1), p: 1318.

Bulgurlu, S. and M. Ergul. 1978. Physical, chemical and biological analyses methods of feeds. Izmir, Ege Univ. Agric. Fac. Publish No: 127 (in Turkish).

Dale, L.M., I. Rotar, A. Thewis, R. Vidican, V. Florian and A. Ciure. 2012. Determination of alfalfa crude fiber, ndf, adf and lignin content by nir spectrometry. Lucrări Ştiintifice, vol. 55, seria Agronomie, p: 245-249.

Erkovan, H.I., M.K. Gullap, M. Dasci and A. Koc. 2009. Changes in leaf area index forage quality and above-ground biomass in grazed and ungrazed rangelands of eastern anatolia region. Journal of Agricultural Sciences, 15 (3), p: 217-223.

Forbes, J.C. and R.D. Watson. 1992. Plants in agriculture. Cambridge University Pres., Cambridge, 355p.

Geren, H., B. Kir, G. Demiroglu and Y.T. Kavut. 2009. Effects of different soil textures on the yield and chemical composition of alfalfa (Medicago sativa L.) cultivars under mediterranean climate conditions. Asian Journal of Chemistry, 21 (7), p: 5517-5522.

Jarrige, R. 1988. Alimentation des bovins, ovins et caprins. INRA Paris, 471p.

Kacar, B. and A. Inal. 2008. Plant analysis. Ankara, Nobel Publish No:1241, 892p (in Turkish).

Kiraz, A.B. 2011. Determination of relative feed value of some legume hays harvested at flowering stage. Asian Journal of Animal and Veterinary Advances, 6 (5), p: 525-530.

Mala, A.S.E.E. and B. Fadlala. 2013. Effect of stage of cutting alfalfa (berseem) on crude protein content and dry matter yield. ARPN Journal of Science and Technology, 3 (10), p: 982-985.

Markovic, J., J. Radovic, Z. Lugic and D. Sokolovic. 2007. The effect of development stage on chemical composition of alfalfa leaf and stem. Biotechnology in Animal Husbandry 23 (5-6), p: 383-388.

Meyer, D.W. 2005. Plant height as determinant for harvesting alfalfa. In: Forage Focus, Meyer, D.W. (Ed.). Midwest Forage Association, Minneapolis, USA., p: 12-13.

Moreira, A. and N.K. Fageria. 2010. Liming influence on soil chemical properties, nutritional status and yield of alfalfa grown in acid soil. R. Bas. Ci. Solo, 34, p:1231-1239.

Rechel, E.A., B.D. Meek, W.R. DeTar and L.M. Carter. 1991. Alfalfa yield as affected by harvest traffic and soil compaction in a sandy loam soil. Journal of Production Agriculture (4) 2, p: 241-246.

Riday, H. and E.C. Brummer. 2005. Relationships among biomass yield components within and between subspecies of Alfalfa. http://naldc.nal.usda.gov/naldc/download.xhtml?id $=16387 \&$ content $=$ PDF (Accessed November 24, 2014).

Rohweder, D.A., R.F. Barnes and N. Jorgensen. 1978. Proposed hay grading standards based on laboratory analyses for evaluating quality. Journal Animal Sci., 47, p: 747-759.

Saruhan, V. and A. Kusvuran. 2011. Determination of yield performances of some lucerne (medicago sativa 1) cultivars and genotypes under the Southeastern Anatolian region conditions. Journal of the Faculty of Agriculture, Izmir, 48 (2), p: 133-140 (in Turkish). 
Selmi, H., Z. Abdelwahed, A. Rouissi, B. Jemmali, L. Tayachi, M. Amraoui and H. Rouissi. 2013. Preliminary nutritional characterization of some shrubs from the north of Tunisia. International Journal of Research in Agriculture and Food Sciences. 1 (1), p: 36-39.

Sengul, S., L. Tahtacioglu and A. Mermer. 2003. Determination of suitable alfalfa (Medicago sativa L) cultivars and lines for Eastern Anatolia Region. Journal of the Faculty of Agriculture, Erzurum, 34 (4), p: $321-325$ (in Turkish).

Sheaffer, C.C., D. Cash, N.J. Ehlke, J.L. Hansen, J.C. Henning, J. Grimsbo Jewett, K.D. Johnson, M.A. Peterson, M. Smith and D.R. Viands. 1998. Entry x environment interactions for alfalfa forage quality. Agronomy Journal, 90, p: 774-780.
Soya, H., R. Avcioglu and H. Geren. 2004. Forage crops, Hasad Press, Turkey, 223p (in Turkish).

Steel, R.G.D. and J.H. Torrie 1980. Principles and procedures of statistics, second edition, New York: McGraw-Hill.

Tomic, Z., Z. Nesic, V. Krnjaja, M. Zujovic and M.M. Petrovic. 2006. Forage production and quality of some new legume cultivars in Serbia. Sustainable grassland productivity: Proceedings of the $21^{\text {st }}$ General Meeting of the European Grassland Federation, Badajoz, Spain, p: 282-284.

Tongel, M.O. and I. Ayan. 2010. Nutriotional contents and yield performances of lucerne (medicago sativa 1.) cultivars in southern black sea shores. Journal of Animal and Veterinary Advances, 9 (15), p: 2067-2073. 